\title{
WeEd InTERFerence on Growth AND Yield of TRANSGenic MaIze ${ }^{1}$
}

\author{
Interferência de Plantas Daninhas sobre o Crescimento e a Produtividade de Milho Transgênico
}

FARIA, R.M. ${ }^{2}$, BARROS, R.E. ${ }^{2}$, and TUFFI SANTOS, L.D. ${ }^{2}$

\begin{abstract}
Plants kept under competition tend to modify their morphology to optimize the use of production factors. This study aimed to evaluate the effects of competition between transgenic maize and five weed species on the growth and yield of transgenic maize hybrid. The experiment used a randomized block design with four replicates in a factorial $5 \times 2+6$ scheme consisting of a combination of maize under competition with five weed species (Bidens pilosa, Commelina benghalensis, Brachiaria brizantha, Sorghum arundinaceum and Ipomoea triloba) in two weed densities (15 or 30 plants $\mathrm{m}^{-2}$ ) plus six treatments corresponding to maize and weed species without competition. All the means for dry matter accumulated by maize plants in the stem and leaf in the density of 15 plants $\mathrm{m}^{2}$ were higher than the means for plants in coexistence with 30 plants $\mathrm{m}^{-2}$. Number of kernels, diameter and length of cob were not affected by competition with weeds. The weeds that most interfered with maize biomass production were $S$. arundinaceum and B. brizantha. Leaf dry mass accumulation was more sensitive than the production of stem. It was observed that maize was usually very competitive with weeds, and there was a strong decrease in dry matter accumulation of all the weeds in the study when in coexistence with the crop.
\end{abstract}

Keywords: competitive ability, Brachiaria brizantha, Commelina benghalensis, Bidens pilosa, Sorghum arundinaceum, Ipomoea triloba.

\begin{abstract}
RESUMO - Plantas mantidas sobre competição tendem a modificar sua morfologia para o maior aproveitamento dos fatores de produção. Objetivou-se no presente estudo avaliar a interferência de plantas daninhas em duas densidades sobre o crescimento e a produção de híbrido de milho transgênico. O experimento foi instalado em blocos casualizados com quatro repetições, arranjado em esquema fatorial $5 \times 2+6$. No fator 1 alocaram-se as espécies Bidens pilosa, Commelina benghalensis, Brachiaria brizantha, Sorghum arundinaceum e Ipomoea triloba, e no fator 2, as densidades de plantas daninhas (15 ou 30 plantas $m^{-2}$ ) mantidas em convivio com o híbrido de milho transgênico DKB 390 PRO 2. Mantiveram-se seis tratamentos adicionais, correspondendo às plantas daninhas e a o milho ausentes de competição. Todas as médias de massa seca acumuladas pelo milho no caule e nas folhas na densidade de 15 plantas daninhas $\mathrm{m}^{2}$ foram superiores às médias apresentadas pelas plantas em convivio com 30 plantas daninhas $\mathrm{m}^{-2}$. O número de grãos, o diâmetro e o comprimento de espiga do milho não foram influenciados pela competição com as plantas daninhas. As plantas daninhas que mais interferiram na produção de massa seca do milho foram $\mathbf{S}$. arundinaceum e B. brizantha. O acúmulo de massa seca foliar do milho é mais sensivel ao convivio que o de massa seca caulinar. De modo geral, o milho apresentou boa habilidade competitiva com as plantas daninhas, constatando-se decréscimo no acúmulo de massa seca de todas as espécies quando em convivência com a cultura.
\end{abstract}

Palavras-chave: habilidade competitiva, Brachiaria brizantha, Commelina benghalensis, Bidens pilosa, Sorghum arundinaceum, Ipomoea triloba.

Recebido para publicação em 2.2.2014 e aprovado em 25.4.2014.

Universidade Federal de Minas Gerais, Montes Claros-MG, Brasil, <rmf_faria@yahoo.com.br>.

Planta Daninha, Viçosa-MG, v. 32, n. 3, p. 515-520, 2014 


\section{INTRODUCTION}

Maize (Zea mays) is a major cereal grown worldwide, providing products for various industries - including human and animal foods - and raw materials for industry. Brazil currently stands out as one of the largest maize producers in the world, with an estimated production of 79,000 tonnes in the 2013/2014 harvest (CONAB, 2013). However, Brazilian productivity per hectare is considered to be low, estimated at $5,108 \mathrm{~kg} \mathrm{ha}^{-1}$ (CONAB, 2013), which is almost half of the average production of North American crops, which is approximately $10,000 \mathrm{~kg} \mathrm{ha}^{-1}$ (USDA, 2013).

One of the factors that negatively affect the yield of maize is weed interference, whereby weeds may directly compete with crops for nutrients, water, space and light, and also indirectly, when they are alternative hosts to pathogens and insect pests, or when they hinder harvesting. Weed-crop competition is influenced by weed species, density and population in crops (Zanine $\&$ Santos, 2004).

Coexistence with weeds can modify plant morphology (Wandscheer \& Rizzardi, 2013), biomass accumulation, plant growth (Rajcan $\&$ Swanton, 2001) and, successively, the yield of crops of interest (Rajcan \& Swanton, 2001; Bianchi et al., 2006; Marquardt et al., 2012; Cerrudo et al., 2012). Such coexistence may cause species to accumulate less biomass (Mohammadi, 2007), although growth and productive capacity of crops may remain unaltered (Cerrudo et al., 2012; Wandscheer \& Rizzardi, 2013).

Genes of interest are inserted into genetically modified organisms, providing a given crop with desired traits. For DKB 390 PRO 2 maize, there are two technologies that make it resistant to the herbicide glyphosate and caterpillar pests. These changes may not directly interfere with the adaptability of the plant to the environment, but different management of transgenic compared with nontransgenic maize makes pest control easier and reduces costs (Wolfenbarger $\&$ Phifer, 2000).

Despite the importance of competitive adaptation of plants to the productive sector, there are few studies evaluating the interference of weeds in competition with genetically modified maize. In this context, the objective of the present study was to evaluate the effect of weeds in two densities on the yield and growth of transgenic maize hybrids.

\section{MATERIAL AND METHODS}

The experiment was set up in open environement, between the months of September and December 2012, at longitude $43^{\circ} 51^{\prime} 53^{\prime \prime} \mathrm{W}$, latitude $16^{\circ} 44^{\prime} 13^{\prime \prime} \mathrm{S}$ and $650 \mathrm{~m}$ of altitude. According to the Köppen classification, the region has climate Tropical Savanna (Aw), with hot, rainy summers and dry winters. The experiment was conducted in plastic pots with volumetric capacity of $12 \mathrm{~L}$, filled with substrate composed of eutrophic Red-Yellow Podzol, manure and sand in a ratio of $3: 1: 1$, respectively. The substrate had a medium texture, $\mathrm{pH}$ (water) $=6.8, \mathrm{P}=490 \mathrm{mg} \mathrm{kg}^{-1}, \mathrm{~K}=$ $159 \mathrm{mg} \mathrm{kg}^{-1}, \mathrm{Ca}=9.5 \mathrm{cmol} \mathrm{dm}^{-3}, \mathrm{Mg}=$ $4.7 \mathrm{cmol} \mathrm{dm}^{-3}, \mathrm{Al}=0.0 \mathrm{cmol} \mathrm{dm}^{-3}, \mathrm{H}+\mathrm{Al}=$ $0.86 \mathrm{cmol} \mathrm{dm}^{-3}$, effective CEC $=14.61 \mathrm{cmol} \mathrm{dm}^{-3}$ and organic matter content $=7.61 \mathrm{daq} \mathrm{kg}^{-1}$.

The experiment was set up in a randomized block design with four replications arranged in a factorial $5 \times 2+6$ scheme. The first factor was comprised of the species Bidens pilosa, Commelina benghalensis, Brachiaria brizantha, Sorghum arundinaceum and Ipomoea triloba, and the second, of weed densities (15 or 30 plants $\mathrm{m}^{2}$ ) in coexistence with GM maize hybrid DKB 390 PRO 2. There were also six additional treatments, corresponding to weeds and maize without competition.

The weeds were sown on polyethylene trays and grown until they reached about $5 \mathrm{~cm}$. They were subsequently transplanted to pots, where maize seedling emergence was taking place. The pots were watered three times a day throughout the experimental period, and fertilized according to the recommendations for maize crops (Alves, 1999). Two densities in coexistence with maize were evaluated: 15 and 30 plants $\mathrm{m}^{-2}$. Considering the size of the pot, this represents 1 and 2 plants pot ${ }^{-1}$, respectively.

The coexistence period was 78 days, corresponding to the reproductive stage 3 (milky kernel or sweetcorn), when the 
destructive evaluation of the weeds and the crop was performed. The ears were collected and the following were measured: fresh weight, diameter, length and number of grains as well as weight of husk. The weeds and maize plants were pulled out from the pots and separated into stems and leaves. After collection and separation, all the material was dried in a forced air circulation oven at $65{ }^{\circ} \mathrm{C}$ for 72 hours until constant weight; total dry weight and dry weight for each organ (leaves and stem) were measured.

After determination of dry weight, total dry matter production between treatments and distribution in each organ were compared with total dry matter. In the three species of grasses used in the experiment, the leaf was formed by leaf blade + sheath.

Data underwent analysis of variance and significant means were compared by Tukey's test at $5 \%$ probability.

\section{RESULTS AND DISCUSSION}

Number of kernels, diameter and length of ear were not influenced by association with Bidens pilosa, Commelina benghalensis, Brachiaria brizantha, Sorghum arundinaceum and Ipomoea triloba, regardless of weed density. Interaction was observed $(\mathrm{p}<0.05)$ among the factors weed species and density for shoot dry matter of maize.

Shoot dry matter of maize in association with 15 plants $\mathrm{m}^{-2}$ showed no changes for the interaction with weeds (Table 1). The increase in density from 15 to 30 plants $\mathrm{m}^{2}$ of $B$. brizantha or $S$. arundinaceum reduced shoot dry matter accumulation of the crop. This was not observed for the other association arrangements of the present study (Table 1). $B$. brizantha has high ability to absorb nitrogen (Jakelaitis et al., 2006). This nutrient is closely associated with growth and nutritional quality of maize (Gholamhoseini et al., 2012).

The coexistence of $S$. arundinaceum in the density of 30 plants $\mathrm{m}^{-2}$ caused greater interference in the shoot dry matter of maize (Table 1), in addition to lower dry matter accumulation in the stem, leaf and ear husks, compared with control (Table 2). $S$. arundinaceum was more competitive than other weeds. Considering competition for light, the highest weeds significantly interfere with the development and yield of maize (Jakelaits et al., 2004).

Table 1 - Shoot dry matter (SDM) of maize plants under the interference of different weed densities after 78 days of coexistence

\begin{tabular}{|c|c|c|}
\hline \multirow{2}{*}{ Coexisting weeds } & \multicolumn{2}{|c|}{ SDM of maize ( $\mathrm{g}$ per plant) } \\
\hline & 15 plants $\mathrm{m}^{-2}$ & 30 plants $\mathrm{m}^{-2}$ \\
\hline Brachiaria brizantha & $275.24 \mathrm{Aa}$ & $227.60 \mathrm{Bb}$ \\
\hline Commelina benghalensis & $256.15 \mathrm{Aa}$ & $255.32 \mathrm{Aba}$ \\
\hline Bidens pilosa & $238.29 \mathrm{Aa}$ & $230.42 \mathrm{Aba}$ \\
\hline Sorghum arundinaceum & $235.19 \mathrm{Aa}$ & $165.74 \mathrm{Cb}$ \\
\hline Ipomoea triloba & $266.16 \mathrm{Aa}$ & $239.30 \mathrm{Aba}$ \\
\hline Control $^{1 /}$ & \multicolumn{2}{|c|}{$275.32 \mathrm{Aa}$} \\
\hline $\mathrm{CV} \%{ }^{2 / 1}$ & \multicolumn{2}{|c|}{8.73} \\
\hline
\end{tabular}

Means followed by the same capital letter in the column do not differ by the F-test at $5 \%$ probability; Means followed by the same lowcase letter in the line do not differ by Tukey's test at $\mathrm{p}<0.05$ test; $\stackrel{1 /}{ }$ Maize plant control without coexistence with weeds, $\stackrel{2}{ }$ Coefficient of variation.

Table 2 - Dry matter of leaf, stem, ear and husk under weed interference after 78 days of coexistence

\begin{tabular}{|c|c|c|c|c|}
\hline \multirow{2}{*}{ Weed } & \multicolumn{4}{|c|}{ Dry weight } \\
\hline & Leaf & Stem & Ear & Husk \\
\hline Brachiaria brizantha & $111.92 \mathrm{~B}$ & $139.49 \mathrm{~A}$ & $258.83 \mathrm{~B}$ & $182.98 \mathrm{BC}$ \\
\hline Commelina benghalensis & $115.71 \mathrm{AB}$ & $140.01 \mathrm{~A}$ & $284.07 \mathrm{AB}$ & $254.68 \mathrm{AB}$ \\
\hline Bidens pilosa & $104.63 \mathrm{BC}$ & $129.71 \mathrm{AB}$ & $241.44 \mathrm{~B}$ & $178.93 \mathrm{BC}$ \\
\hline Sorghum arundinaceum & $89.84 \mathrm{C}$ & $110.62 \mathrm{~B}$ & $223.12 \mathrm{~B}$ & $147.89 \mathrm{C}$ \\
\hline Ipomoea triloba & $112.13 \mathrm{~B}$ & $140.59 \mathrm{~A}$ & $266.85 \mathrm{~B}$ & $192.64 \mathrm{BC}$ \\
\hline Control $^{1 /}$ & $130.69 \mathrm{~A}$ & $144.62 \mathrm{~A}$ & $344.21 \mathrm{~A}$ & $284.07 \mathrm{~A}$ \\
\hline $\mathrm{CV} \%{ }^{2 /}$ & 9.14 & 11.40 & 18.72 & 24.28 \\
\hline
\end{tabular}

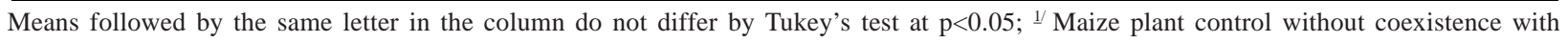
weeds; $\stackrel{2}{ }$ Coefficient of variation. 
In the two densities, Commelina benghalensis, Bidens pilosa and Ipomoea triloba plants caused a small reduction in the shoot dry matter of maize, with no significant difference with the crop grown in monoculture. Lemos et al. (2012) reported that higher densities of $B$. pilosa and $C$. benghalensis, if not controlled properly, can lead to losses in maize crops. Although I. triloba caused little decrease in maize biomass, special attention should be paid to it, because it has varying growth habit and develops on crops of interest, forming a dense tangle that creates major complications for manual and mechanized harvesting.

Dry matter accumulation in the leaf, stem and ear of transgenic maize was similar in the density of 15 plants $\mathrm{m}^{-2}$ and for the crop grown in monoculture; they were both higher than the density of 30 plants $\mathrm{m}^{-2}$. These variables were not influenced $(p<0.05)$ by the interaction between weeds and their densities. Among the weed species studied, only for $C$. benghalensis in association with maize, production of leaf shoot dry matter was equivalent to that of control (Table 2). Dry matter accumulation in the stem was less influenced by association with weeds; only the presence of $S$. arundinaceum caused reduction in stem dry weight of the grown plant (Table 2). Maize plants in association with $B$. brizantha, B. pilosa, $S$. arundinaceum and $I$. triloba had similar decrease in the dry matter of ears (Table 2).

It should be noted that the transplanting technique was used for the weeds; thus, the size of maize plants and weeds was matched, when the weeds were inserted into the experimental plots. Considering that time of weed germination is closely associated with competitive potential, the earlier weeds germinate, the more they interfere (Fleck et al., 2004). Growth and dry matter production by weeds are much more closely associated with availability of resources and competitive ability than the genetic potential of the species itself (Obara et al., 1994). As competition for resources is reciprocal, the development of the weed community is also influenced by maize (Marquardt et al., 2012). Thus, planting genetic materials that compete more effectively for factors of production is crucial for weed suppression (Azeez, 2009; Wandscheer \& Rizzardi, 2013).

Planta Daninha, Viçosa-MG, v. 32, n. 3, p. 515-520, 2014
Biomass accumulated by weeds in association with maize was similar in the densities of 15 and 30 plants $\mathrm{m}^{-2}$ and lesser than that of control grown in monoculture, for all the species studied (Table 3 ). These results can be attributed to increased interspecific interference caused by the maize plant, even in association with twice as much population of weeds.

Leaf dry matter production of $B$. brizantha, $S$. arundinaceum and $I$. triloba was not different for the two densities tested, and these were lower than the respective controls (Table 4). B. pilosa accumulated the same amount of leaf dry matter in the two densities when in association with maize and when grown in monoculture. Regarding the studied weeds, there were no differences in leaf dry matter in the two densities evaluated in association with maize (Table 4). However, when grown in monoculture, $B$. brizantha and $S$. arundinacearum showed greater leaf accumulation compared with the others (Table 4). Thus, leaf dry matter production is reduced in competitive environments for these two species.

Commelina benghalensis, Bidens pilosa, Sorghum arundinaceum and Ipomoea triloba showed the same behavior for stem dry matter production, where the means of the control

Table 3 - Shoot dry matter of weeds in two densities after 78 days of coexistence with maize plants

\begin{tabular}{|c|c|}
\hline Coexisting weeds & $\begin{array}{l}\text { Shoot dry matter of } \\
\text { weeds ( } \mathrm{g} \text { per plant) }\end{array}$ \\
\hline Brachiaria brizantha & $120.53 \mathrm{~B}$ \\
\hline Commelina benghalensis & $99.38 \mathrm{~B}$ \\
\hline Bidens pilosa & 149.86B \\
\hline Sorghum arundinaceum & $242.70 \mathrm{~A}$ \\
\hline Ipomoea triloba & $114.40 \mathrm{~B}$ \\
\hline $\mathrm{CV} \%$ & 34.58 \\
\hline $\begin{array}{c}\text { Density of coexistence } \\
\left(\text { plants } \mathrm{m}^{-2}\right)\end{array}$ & $\begin{array}{l}\text { Shoot dry matter of } \\
\text { weeds ( } \mathrm{g} \text { per plant) }\end{array}$ \\
\hline 15 & $108.51 \mathrm{~B}$ \\
\hline 30 & $75.42 \mathrm{~B}$ \\
\hline Control $^{1 /}$ & $252.39 \mathrm{~A}$ \\
\hline $\mathrm{CV} \%$ & 34.58 \\
\hline
\end{tabular}

Means followed by the same letter in the column do not differ by Tukey's test at $\mathrm{p}<0.05 ;{ }^{1 /}$ Maize plant control without coexistence with weeds; $\stackrel{2}{ }$ Coefficient of variation. 
Table 4 - Leaf dry matter in grams per plant of weeds in coexistence with maize in two densities and controls after 78 days of coexistence

\begin{tabular}{|c|c|c|c|}
\hline \multirow{3}{*}{ Coexisting weed } & \multicolumn{3}{|c|}{ Leaf dry matter ( $g$ per plant) } \\
\hline & \multicolumn{3}{|c|}{ Density of coexistence } \\
\hline & 15 plants $\mathrm{m}^{-2}$ & 30 plants $\mathrm{m}^{-2}$ & Control $^{1 /}$ \\
\hline Brachiaria brizantha & $65.49 \mathrm{Ab}$ & $44.90 \mathrm{Ab}$ & $118.51 \mathrm{Aa}$ \\
\hline Commelina benghalensis & $37.49 \mathrm{Aab}$ & $15.78 \mathrm{Ab}$ & $58.80 \mathrm{Ba}$ \\
\hline Bidens pilosa & $35.51 \mathrm{Aa}$ & $31.47 \mathrm{Aa}$ & $49.87 \mathrm{Ba}$ \\
\hline Sorghum arundinaceum & $67.19 \mathrm{Ab}$ & $49.34 \mathrm{Ab}$ & $156.51 \mathrm{Aa}$ \\
\hline Ipomoea triloba & $44.29 \mathrm{Ab}$ & $24.12 \mathrm{Ab}$ & $94.18 \mathrm{Ba}$ \\
\hline $\mathrm{CV} \%{ }^{2 !}$ & & 37.0 & \\
\hline
\end{tabular}

Means followed by the same capital letter in the row and lowercase in the column do not differ by Tukey’s test at $\mathrm{p}<0.05$. ${ }^{1 /}$ Maize plant

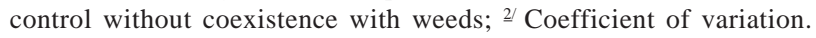

Table 5 - Stem dry matter of weeds in association with maize in two densities and controls after 78 days of coexistence

\begin{tabular}{|c|c|c|c|}
\hline \multirow{3}{*}{ Coexisting weed } & \multicolumn{3}{|c|}{ Stem dry weight (g per plant) } \\
\hline & \multicolumn{3}{|c|}{ Density of coexistence } \\
\hline & 15 plants $\mathrm{m}^{-2}$ & 30 plants $\mathrm{m}^{-2}$ & Control $^{1 / 1}$ \\
\hline Brachiaria brizantha & $25.08 \mathrm{Ba}$ & $18.32 \mathrm{Aa}$ & $36.22 \mathrm{Ba}$ \\
\hline Commelina benghalensis & $43.55 \mathrm{ABb}$ & $24.74 \mathrm{Ab}$ & $117.77 \mathrm{Ba}$ \\
\hline Bidens pilosa & $68.64 \mathrm{ABb}$ & $62.06 \mathrm{Ab}$ & $202.04 \mathrm{Aa}$ \\
\hline Sorghum arundinaceum & $111.14 \mathrm{Ab}$ & $81.06 \mathrm{Ab}$ & $262.54 \mathrm{Aa}$ \\
\hline Ipomoea triloba & $43.19 \mathrm{ABb}$ & $24.98 \mathrm{Ab}$ & $112.44 \mathrm{Ba}$ \\
\hline $\mathrm{CV} \%$ & & 45.0 & \\
\hline
\end{tabular}

Means followed by the same uppercase letter in the column and lowercase letter on the row in each variable (plant organ) do not differ by Tukey's test at $5 \%$ probability. ${ }^{1 /}$ Maize plant control without coexistence with weeds; $\stackrel{2}{2}$ Coefficient of variation.

were higher than those obtained in the density of 15 plants $\mathrm{m}^{-2}$, which were equivalent to those obtained in the density of 30 plants $\mathrm{m}^{-2}$ (Table 5).

S. arundinaceum showed higher stem dry matter accumulation in the density of 15 plants $\mathrm{m}^{-2}$. This was not observed in the density of 30 plants $\mathrm{m}^{-2}$, which is indicative of greater interspecific competition among other species. The species $B$. brizantha was the least influenced for stem dry weight by the competitive arrangements tested, perhaps because of the lower participation of the stem in the shoot of this species. The fact that stem dry matter accumulation was the same in the two densities, for plants grown in monoculture and in competition with maize, can be attributed to greater stem development in the competitive environment. This was a strategy of the weed in an attempt to overcome the shading imposed by the crop.
C. benghalensis and I. triloba were the species that showed the highest relative decrease in stem dry weight at the density of 30 plants $\mathrm{m}^{-2}$, compared with plants grown in monoculture. This is indicative that the aforementioned variable is more sensitive to intraspecific competition in those species than in S. arundinaceum, B. brizantha and $B$. pilosa. The low stem dry matter production of $C$. benghalensis is advantageous for the management of this species, considering that the stem is highly able to develop adventitious roots, perform photosynthesis, accumulate starch reserves and be an efficient means of propagation (Lorenzi, 2006).

It should be noted that $S$. arundinaceum and $B$. pilos $a$ were the only weeds in the study that produced seeds. This faster cycle is an important tool for infestation of the area, although $B$. pilosa is easily controlled when planted directly in the husk, as it is a positively 
photoblastic plant and its germination is hindered at depths greater than $3 \mathrm{~cm}$ (Corrêa et al., 2011).

It is concluded that GM DKB 390 PRO 2 maize has competitive ability against weeds, with no significant reduction in the productive characteristics of the ear; strong decrease was observed in the dry matter accumulation of all the weeds kept in coexistence. Weeds that interfered the most in dry matter production of maize were $S$. arundinaceum and $B$. brizantha, especially in the higher density. The leaf is the organ of the shoot with the most sensitivity to competition for both maize as well as weeds, leading to lower leaf dry matter accumulation in plants kept in coexistence.

\section{LITERATURE CITED}

ALVES, V. M. C. et al. Sugestão de adubação para grandes culturas anuais ou perenes: Milho. In: RIBEIRO, A. C.; GUIMARAES, P. T. G.; ALVAREZ V., V. H. (Ed.).

Recomendação para o uso de corretivos e fertilizantes em Minas Gerais: $5^{a}$ aproximação. Viçosa, MG, Comissão de Fertilidade do Solo do Estado de Minas Gerais, 1999. p. 314-316.

AZEEZ, J. O. Effects of nitrogen application and weed interference on performance of some tropical maize genotypes in Nigeria. Pedosphere, v. 19, n. 5, p. 654-662, 2009.

BIANCHI, M. A.; FLECK, N. G.; FEDERIZZI, L. C. Características de plantas de soja que conferem habilidade competitiva com plantas daninhas. Bragantia, v. 65, n. 4, p. 623-632, 2006.

CERRUDO, D. et al. Mechanisms of yield loss in maize caused by weed competition. Weed Sci., v. 60, n. 2, p. 225-232, 2012.

COMPANHIA NACIONAL DE ABASTECIMENTO CONAB. Acomp. safra bras. grãos, v. 1 - Safra 2013/14, n. 2 Segundo Levantamento, nov. 2013. Disponível em: <http:// www.conab.gov.br>. Acesso em 14 mar. 2014.

CORRÊA, M. L. P. et al. Dinâmica populacional de plantas daninhas na cultura do milho em função de adubação e manejo. R. Ci. Agron., v. 42, n. 2, p. 354-363, 2011.

FLECK, N. G. et al. Interferência de picão-preto e guanxuma com a soja: efeitos da densidade de plantas e época relativa de emergência. Ci. Rural, v. 34, n. 1, p. 41-48, 2004.
GHOLAMHOSEINI, M. et al. Weeds - Friend or foe? Increasing forage yield and decreasing nitrate leaching on a corn forage farm infested by redroot pigweed. Agric. Ecosyst. Environ., v. 179, n. 1, p. 151-162, 2012.

JAKELAITIS, A. et al. Efeitos de densidade e época de emergência de Brachiaria brizantha em competição com plantas de milho. Acta Sci. Agron., v. 28, n. 3, p. 373-378, 2006.

JAKELAITIS, A. et al. Manejo de plantas daninhas no consórcio de milho com capim-braquiária (Brachiaria decumbens). Planta Daninha, v. 20, n. 3, p. 553-560. 2004.

LEMOS, J. P. et al. Efeito da roçada das espécies Bidens pilosa e Commelina benghalensis nas características morfológicas do milho. R. Bras. Agropec. Sustentável, v. 2, n. 1. p. 32-40, 2012.

LORENZI, H. Manual de identificação e controle de plantas daninhas. 6.ed. Nova Odessa: Instituto Plantarum, 2006. 339 p.

MARQUARDT, P. T. et al. Competitive effects of volunteer corn on hybrid corn growth and yield. Weed Sci., v. 60, n. 4, p. 537-541, 2012.

MOHAMMADI, G. R., Growth parameters enhancing the competitive ability of corn (Zea mays L.) against weeds. Weed Biol. Manag., v. 7, n. 4, p. 232-236, 2007.

OBARA, S. Y.; BEZUTTE, A. J.; ALVES, P. L. C. A. Desenvolvimento e composição mineral do picão-preto sob diferentes níveis de pH. Planta Daninha, v. 12, n. 1 p. 52-56, 1994.

RAJCAN, I.; SWANTON, C. J. Understanding maize-weed competition: resource competition, light quality and the whole plant. Field Crops Res., v. 71, p. 139-150, 2001.

WANDSCHEER, A. C. D.; RIZZARDI, M. A. Interference of soybean and corn with Chloris distichophylla.

Ci. Agrotec., v. 37, n. 4, p. 306-312, 2013.

WOLFENBARGER, L. L.; PHIFER, P. R. The ecological risks and benefits of genetically engineered plants. Science, v. 290, n. 1, p. 2088-2093, 2000.

UNITED STATES DEPARTMENT OF AGRICULTURE USDA. Alimente year in review. 2013. 32 p.

ZANINE, A. M.; SANTOS, E. M. Competição entre espécies de plantas - uma revisão. R. Fac. Zootec. Vet. Agron., v. 11, n. 1, p. 10-30, 2004. 